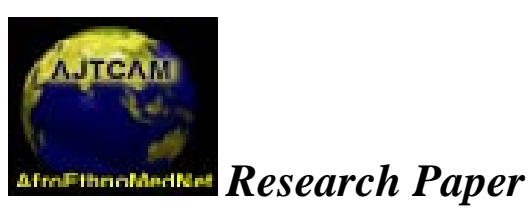

Afr. J. Infect. Diseases

www.africanethnomedicines.net

\title{
MICROBIAL UTILIZATION OF THE HYDROCARBON COMPONENTS OF ATRAZINE IN A TROPICAL SOIL ENVIRONMENT SOUTHWEST, NIGERIA.
}

\author{
O. A. Ojo \\ Department of Microbiology, Lagos State University, \\ Badagry Expressway, Lagos -Nigeria. \\ E- Mail : solayom@yahoo.com
}

\begin{abstract}
Biodegradation of atrazine, a xenobiotic-substance recently introduced into agricultural practice in Nigeria was assessed using native soil microorganisms. Field experiment and laboratory studies confirmed that microbial consortium utilize the hydrocarbon component of atrazine and thereby mineralize the somewhat recalcitrant organic chemical. The atrazine-degraders were isolated on Minimal salt medium and Sabouraud dextrose agar supplemented with atrazine at $0.05 \mathrm{~g} / \mathrm{L}$ and incubated at $28 \pm 2^{\circ} \mathrm{C}$ for 72 hrs and 5 days respectively. The sampled agricultural soil was of alkaline $\mathrm{pH}$ while the optimum $\mathrm{pH}$ at which the microbial consortium metabolizes atrazine was acidic (mean $\mathrm{pH}$ 5.63). Total viable count of bacterial atrazine-degraders was $602.5 \times 10^{5} \mathrm{cfu} / \mathrm{ml}$. Bacterial atrazine-degraders were: Micrococcus sp., Bacillus sp. Enterobacter Sp and Pseudomonas sp. while fungal atrazine-degraders were: Aspergillus fumigatus, A. niger, Penincillium sp and Fusarium sp.
\end{abstract}

Key words: Agriculture, Atrazine, Biodegradation, Herbicides, Sustainable development, Xenobiotic

\section{Introduction}

The pollution of the environment with man-made organic compound has become such an evident issue that it needs no further introduction. Microorganisms play a major role in the breakdown and mineralization of these pollutants (Alexander, 1981).Halogenated compounds are not uncommon in nature and are responsible for the evolution of an extensive range of enzymes, pathways and control mechanism by microorganisms that are responsible for the catabolism of a wide variety of halogenated xenobiotics (Rasul et. al, 1991; Fetzner and Lingens, 1994). In natural systems, a significant proportion of xenobiotics degradation involves co-metabolism, a process in which the partial oxidation of a substance (primary degradation) is not accompanied by carbon incorporation or energy utilization by the degrading microorganism (Boyle, 1989). Biodegradation is a detoxification mechanism for organic contaminants in soil (Fogarty and Tuovinen, 1990).

Atrazine is a complex aromatic compound used as pre- and post-emergence herbicide for vegetation, Christmas tree plantation in conifers reforestation areas. They are often used for selective weed control, on non-cropped land at higher concentrations for non-selective vegetation control. Herbicides are increasingly being used to enhance crop production by controlling competing vegetation. 2-Chloro- 4- ethyl amino-6-isopropyl amino5-triazine (Atrazine) and 2, 4-dichloro phenoxy-acetic acid (2, 4-D) are two chlorinated aromatic herbicides that have been used for both agriculture and forestry vegetation control (Beste, 1983).

The objective of this study was to isolate and identify the native microbial consortium capable of mineralization of high concentration of atrazine.

\section{Materials and Methods History of sampled field}

The experiments were carried out at the Lagos State University, Ojo, Nigeria. The agricultural field (ADP-farm) was sandy/loam comprising two hectares cultivated to Cassava manihot and two hectares to Zea mays, the remaining being unarable land. Mega Premenstral, a pre-emergence herbicide was applied on the 
farm thrice between June, 1996 and January 1998. Premenstral contains atrazine and metalachlor as the active ingredients.

\section{Sample collection}

Forty-eight core soil samples were collected randomly with a soil auger ( $2.5 \mathrm{~cm}$ inner diameter) at 0 $30 \mathrm{~cm}$ depth from each plot $(20 \mathrm{~cm}$ x $20 \mathrm{~cm})$ from ADP-farmsite at Erikorodo, Lagos. They were kept in black polythene bags and air-dried for five days before sieving with $0.02 \mathrm{~mm}$ mesh, after which isolation of microbial consortium suspected to be involved in degradation of Atrazine commenced. Some grassy weeds were collected from the boundaries of the sampled field for isolation of potential / atrazine-degrading microbes from the rhizoplane. Soil samples were collected from another location with no previous history of atrazine application for control. Overall, fifty-six soil samples were collected; ten grams of soil were taken into seed envelopes from each of the composite soil samples and kept in a cool place prior to the determination of their physico-chemical properties.

\section{Chemicals}

Atrazine (Sigma-Aldrich Co. U.K.), Cycloheximide (Sigma-Aldrich Co.U.K.) Minimal salt medium (Kohleret al., 1988). Nutrient agar (Biotech. Lab. UK.)

\section{Isolation and enumeration of Atrazine-degraders}

Selectively enriched cultures with the ability to use Atrazine as carbon and nitrogen energy source were obtained by spiking the agricultural field thrice in eighteen months at different times with Premenstral. The native microbial consortium degrading atrazine on the agricultural field were then isolated using soil dilution technique (Krieg, 1984) and Nutrient agar (pH 7.3) supplemented with atrazine at $0.03 \mathrm{~g} / \mathrm{L}$, incubation was at 27 - $30^{\circ} \mathrm{C}$ for 12 days to isolate bacterial consortium while Sabouraud dextrose agar (SDA) supplemented with atrazine at $0.05 \mathrm{~g} / \mathrm{L}$ was used to isolate native fungal population, the plates were incubated at ambient temperature $\left(25-30^{\circ} \mathrm{C}\right)$ in the dark to preclude photolysis reaction for $5-7$ days. Cycloheximide $(50 \mathrm{mg} / \mathrm{L})$ was added to media used for isolation of bacteria (Mandelbaum et al., 1993; Kohler et al., 1988; Alvey and Crowley, 1995). The media were sterilized at $121^{\circ} \mathrm{C}$ for 15 minutes. The atrazine stock solution was prepared in methanol $(50 \mathrm{mg} / \mathrm{ml})$ and was shaken vigorously for several hours prior to incorporation into the medium. The atrazine stock solution was stored unfiltered at room temperature in the dark.

\section{Enumeration of bacterial consortium}

Bacterial atrazine-degraders were enumerated by preparing a ten-fold dilution series with two replications per dilution with the soil dilutions as inoculants on two growth media; nutrient agar and minimal salt agar supplemented with atrazine at $0.05 \mathrm{~g} / \mathrm{L}$ and $0.03 \mathrm{~g} / \mathrm{L}$ respectively as well as incubation at $27-30^{\circ} \mathrm{C}$ for 12 days. The two methods are similar to the Most Probable Number (MPN) method. The distinct bacterial colonies were counted using Quebec's colony counter (Model 3328 Buffalo NY 14420). The controls were uninoculated plates containing the media used.

\section{Atrazine-degraders assay}

Several aseptic transfers of bacterial isolates on Nutrient medium and Minimal salt medium each supplemented with atrazine at $0.05 \mathrm{~g} / \mathrm{L}$ and $0.03 \mathrm{~g} / \mathrm{L}$ respectively were incubated at $27-30^{\circ} \mathrm{C}$ for 12 days to develop subcultures which culminates in preparation of pure cultures of each isolate (Kohler et al., 1988; Mandelbaum et al., 1993). Native fungal population were assayed using SDA supplemented with 0.05 g/L of atrazine several aseptic transfers of fungal mycelia were done on this medium and the plates were incubated at ambient temperature for 5 - 7 days. The controls were uninoculated plates containing the media used.

\section{Identification of bacterial atrazine-degraders}

Identification of the different bacterial strains was carried out using the Bergey's manual of Determinative Bacteriology (1974). Bacterial pure cultures were identified based on the following criteria;

(i) Growth on laboratory media supplemented with Atrazine

(ii) Colonial morphology and pigmentation compared with those of standard pure cultures. 
Table 1: Physico - chemical properties of soil samples.

\begin{tabular}{|c|c|c|c|c|c|c|c|c|c|c|c|c|c|c|c|}
\hline Description & $\mathrm{pH}$ & $\begin{array}{l}\% \\
\text { Sand }\end{array}$ & $\begin{array}{l}\% \\
\text { Silt }\end{array}$ & $\begin{array}{l}\% \\
\text { Clay }\end{array}$ & $\begin{array}{l}\mathrm{Meq} / 10 \mathrm{~g} \\
\mathrm{Ca}\end{array}$ & Meq/100g & Meq/100g & Meq/100g & Meq/100g & C.E.C & $\begin{array}{l}\% \\
\mathrm{C}\end{array}$ & $\begin{array}{l}\% \\
\mathrm{~N}\end{array}$ & $\begin{array}{l}\text { Av. P } \\
\text { PPM }\end{array}$ & $\mathrm{SO}_{4}{ }^{2-}$ & $\mathrm{Cl}^{-}$ \\
\hline North & 5.85 & 75.4 & 16.4 & 8.2 & 1.09 & 0.88 & 0.11 & 0.33 & 0.12 & 2.53 & 1.33 & 0.13 & 6.41 & 38.62 & 71.35 \\
\hline South & 5.80 & 71.4 & 18.4 & 10.2 & 0.91 & 0.94 & 0.09 & 0.34 & 0.12 & 2.40 & 1.44 & 0.14 & 5.50 & 41.38 & 86.36 \\
\hline West & 6.10 & 63.4 & 22.4 & 14.2 & 0.74 & 1.19 & 0.11 & 0.43 & 0.11 & 2.58 & 1.54 & 0.15 & 5.04 & 21.69 & 43.86 \\
\hline East & 5.90 & 71.5 & 20.4 & 8.1 & 0.58 & 1.00 & 0.10 & 0.30 & 0.12 & 2.10 & 1.31 & 0.13 & 4.58 & 32.74 & 64.61 \\
\hline
\end{tabular}

Meq/100g = Milliequivalent per100g

C. E. C = Cations Exchange Capacity

Av. $\mathrm{P}=$ Available Phosphorus

\% C = Percentage Carbon

Table 2: Micromorphology and biochemical characterization of bacterial atrazine-degraders

\begin{tabular}{|c|c|c|c|c|c|c|c|c|c|c|c|c|c|c|c|c|c|c|}
\hline 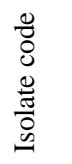 & 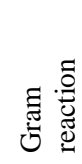 & 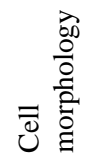 & 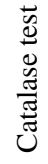 & 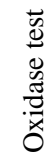 & 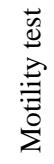 & 苞: & 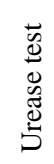 & 乙。 & 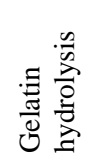 & 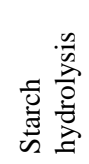 & 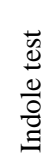 & 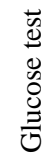 & 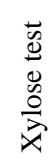 & 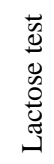 & 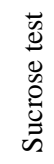 & 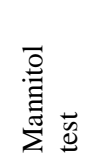 & 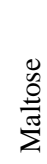 & $\begin{array}{l}\text { E్ } \\
. \overparen{\Xi} \\
\widetilde{0} \\
0 \\
0\end{array}$ \\
\hline LW1 & + & Rods & + & + & + & + & - & + & + & + & - & + & - & + & + & + & - & B. subtilis \\
\hline LW2 & - & Rods & + & - & + & + & - & - & + & + & - & + & + & + & + & + & + & $\begin{array}{c}\text { Enterobacter } \\
\text { aerogenes }\end{array}$ \\
\hline PW1 & + & Rods & + & + & + & + & - & + & + & + & - & + & - & + & + & + & - & B. subtilis \\
\hline PW2 & + & Rods & + & + & + & - & - & - & - & - & - & + & + & - & - & + & + & Micrococcus \\
\hline PW3 & - & Rods & + & - & + & + & - & + & + & - & - & + & + & - & + & + & + & Pseudomonas \\
\hline
\end{tabular}

Table 3: Mean spectrophotometric readings of biodegradation residues at 652nm

\begin{tabular}{|l|l|l|l|l|}
\hline Isolate code & Day 2 & Day 5 & Day 15 & Mean \\
\hline & 0.255 & 0.521 & 0.431 & 0.402 \\
\hline
\end{tabular}

\begin{tabular}{|l|l|l|l|l|}
\hline $\mathrm{LW} 1$ & 0.255 & 0.521 & 0.431 & 0.402 \\
\hline $\mathrm{LW} 2$ & 0.361 & 0.604 & 0.492 & 0.486 \\
\hline $\mathrm{LW}_{1}$ & 0.304 & 0.604 & 0.478 & 0.462 \\
\hline $\mathrm{PW}_{2}$ & 0.226 & 0.481 & 0.374 & 0.360 \\
\hline $\mathrm{PW}_{3}$ & 0.204 & 0.427 & 0.326 & 0.319 \\
\hline
\end{tabular}


(iii) GRAM stain reaction

(iv) Biochemical reactions; standard methods were followed for cytochrome oxidase test, catalase test, motility test, indole, and glucose fermentation/oxidation tests, nitrate reduction test (Collins et al. 1989).

\section{Identification of fungal Atrazine-degraders}

Colonial morphology on SDA supplemented with atrazine at $0.05 \mathrm{~g} / \mathrm{L}$ for 5 - 7 days at ambient temperature was used for preliminary identification of pure cultures of fungal isolates as well as the structural features such as pigmentation of mycelia using Smith’s Introduction to industrial mycology (1981).

\section{Microscopical examination}

After several aseptic transfers of fungal mycelia on SDA plates supplemented with Atrazine at $0.05 \mathrm{~g} / \mathrm{L}$ and incubated at ambient temperature, they were mounted and stained with Lactophenol cotton blue on glass slide. They were then examined under the light microscope at x 40 and the photomicrographs were obtained in order to compare them with standard photomicrographs (Smith, 1981).

\section{Results}

The results are shown in Tables 1 to 3 .

\section{Discussion and Conclusion.}

Previous studies have shown that atrazine is biodegraded by soil mixed cultures (Ojo, 2000) and single cultures (Ojo, 2000; Jessee et al., 1983). The enrichment cultures differed from cultures previously used in the cultures were raised with the same concentration of atrazine used eight years ago, having atrazine as the sole carbon nitrogen and energy source. This method was used in previous trials to obtain s-triazine-degrading bacteria .Growth of microbial species on the culture plates corroborated earlier findings that microbial utilization of hydrocarbon component of herbicides takes place as a means of its mineralization. (Alvey and Crowley, 1995)..The physico-chemical properties of the agricultural soil used for this study confirmed previous discovery of the importance of $\mathrm{C}$ and $\mathrm{N}$ energy source as a factor that regulates the rate of mineralization of atrazine in soil (Mandelbaum et al., 1993).

Soil composition analysis revealed that $\mathrm{No}_{3}-\mathrm{N}$ and \% organic $\mathrm{C}$ in the soil were low but presence of an adequate starter concentration thus facilitates the metabolism of atrazine in the soil, atrazine provided supplement for $\mathrm{N}$ and $\mathrm{C}$ energy source resulting in the mineralization of atrazine , this corroborates earlier findings (Donnelly et al., 1993).However the presence of a significant atrazine mineralizing microbial population , may have prevented these metabolites N-dealkyl (Metabolites) hydroxy atrazine from accumulating in the growth medium and suggests that the degrader community had a broad susbstrate range for the parent compound and its assorted metabolites (Burkard and Guth, 1981; Moreau and mouvet, 1997). The use of atrazine by bacteria and fungal species as an $\mathrm{N}$ source in soils was further demonstrated by the isolation of a consortium capable of using atrazine as a sole source of $\mathrm{N}$, but which could not grow on agar plates where atrazine was the sole source of $\mathrm{C}$ and $\mathrm{N}$.

Since microbial interactions may vary for different soils or environmental conditions, the results of the current study suggests that evaluation of the physico-chemical properties of an agricultural soil before atrazine application would give a preview of the outcome of such application in terms of enhanced xenobioticdegradation, microbial community population and sustainable agricultural practice rather than simple ecological properties such as $\mathrm{C} / \mathrm{N}$ ratio which may be unstable especially in the tropics because of change in climatic conditions. Presence of sufficient organic matter in soil facilitates the survival and activity of a degrader microbial consortium when inoculated into a soil for bioremediation purposes as confirmed by the results of this study (Alvey and Crowley; 1995; Ojo, 2000; Mandelbaum et al., 1993)

In conclusion, the repeated application of premenstrual on this agriculral field reduced the acclimation time of the native microbial community. Hence; the production of dehalogenases by the herbicide, degraders enhanced the mineralization of the herbicides since the breaking of the carbon-halogen bond is the rate determining step in the process. This study thus confirms atrazine degradation in a tropical environment, soil as well as the bioremediation of xenobiotic- polluted environment using native microorganisms, the bioremediation process 
would be a cost-effective process when microorganisms are used as low in-put natural resource thus ensuring sustainable development.

\section{References}

1. Adams, C.D. and Thurman, E.M. (1991). Formation and transport of the de-ethylatrazine in the soil and the vadase zone. J. Environ. Qual. 20: 540 - 7.

2. Alvey, S. and Crowley, D.E. (1995). Influence of organic amendments on Biodegradation of Atrazine as a nitrogen source. J. of Environ. Qual. 24: 1156 - 1162.

3. Alexander, M. (1981) Biodegradation of chemicals of environment concern. Science 211:132-38.

4. $\quad$ Beste, C. E. (1983). Herbicide handbook of the Weed Science Society of America, $5^{\text {th }}$ (ed.). p. $31-33$ Publ. Weed Science Society of America, Champaign. Illinois.

5. Boyle, M. (1989) The Environment Microbiology of chlorinated aromatic decomposition J. Environ Qual 18:395-402

6. Buchanan, R.E \& Gibbons, N.E. (eds.)(1974) Bergey’s Mnnual of Determinative Bacteriology, $8^{\text {th }}$ edition, p. 217-529.Publ. The Williams \& Wilkins coy. Baltimore.

7. Burkard, N. \& Guth, J.A. (1981). Chemial hydrolysis of 2-chloro- 4, 6-bis (Alkylamino)- 1, 3, 5triazine herbicides and their breakdown in soil under the influence of adsorption. Pestic. Sci. 17: 241 - 5.

8. Collins, C.H., Lyne, P.M \& Grange, J.M. (eds) (1989) In: Collins \& Lyne's Microbiological Methods $6^{\text {th }}$ edition. P. 5 - 15. Publ. Butterworths \& Co. Ltd. London.

9. Donnelly, P.K., Entry, J. \& Crawford, D.L. (1993). Degradation of atrazine and 2, 4dichlorophenocyacetic acid by Mycorrhizal fungi at three nitrogen concentrations in- vitro. Appl. Environ. Microbiol. 59: 2642 - 2647.

10. Fetzner, S. \& Lingens, F. (1994). Bacterial dehalogenases: Biochemistry, Genetics and Biotechnological applications. Microbiol. Reviews 58(4): 641 - 685. Publ. AM. Soc. Of Microbiology.

11. Fogarty, A.M \& Tuovinen, O.H (1990) Microbiological degradation of pesticides in yard waste composting . Microbiol. Rev. Sept. p. 225-233

12. Jessee, J.A., Benoit, R.E., Henricks, A.C., Allen, G.C. \& Neal, J.L. (1983). Anaerobic degradation of cyanuric acid, cysteine and atrazine by a facultatively anaerobic bacterium. Appl. Environ. Microbiol. 45: $97-102$.

13. Kohler, K.P.E., Kohler-Staub, D. \& Focht, D.D. (1988). Co-metabolism of polychlorinated biphenyls: Transformation of Aroclor 1254 by growing bacterial enhanced cell. Appl. Environ. Microbiol. 54: 1940 5.

14. Krieg, N.R. (1984). Enrichment and Isolation In: Manual of methods for General Bacteriology (eds.). Gerhardt, P., Murray, R.G.E., Costilow, R.N., Nester, E.W., Wood, W.A., Krieg, N.R. \& Phillips, G.B. Publ. Am. Soc. for Microbiology. p. 126 - 130.

15. Mandelbaum, R.T., Wackett, L.P. \& Allan, D.L. (1993). Mineralization of the S-triazine Ring of atrazine by stable bacterial mixed cultures. Appl. Environ. Microbiol. 59(6): 1695 - 1701.

16. Moreau, C. \& Mouvet, C. (1997). Sorption and Desorption of Atrazine, De- ethylatrazine and Hydroxy atrazine in soil and Aquifer Solids. J. of Environ. Qual. 26(2): 416 - 23.

17. Ojo, O.A. (2000) Degradation of atrazine (a common herbicide) in a tropical soil by indigenous microbial Population In: Biometry and Quality of life Nokoe, S. (Ed.) Proc. Of SUSAN-IBS Meeting, 23-27 august 1999, Ibadan - Nigeria. SUSAN-IBS, Nairobi-Kenya P.215-222

18. RasuL, G. Chaudhry \& Chapalanima Dugu, S. (1991) biodegradation of halogenated organic Compounds. Microbiol. Rev. March p. 59-79.

19. Smith, G. (1981). Smith's Introduction to Industrial Mycology. $7^{\text {th }}$ edition (Eds.) A.H.S. Onions, D. Allsopp and H.O.W. Eggins. p. 132, - 251 Publ. Pitman Press, Bath. 